\title{
Enhancing local action planning through quantitative flood risk analysis: a case study in Spain
}

\author{
Jesica Tamara Castillo-Rodríguez ${ }^{1}$, Ignacio Escuder-Bueno ${ }^{1,2}$, Sara Perales-Momparler ${ }^{3}$, and \\ Juan Ramón Porta-Sancho ${ }^{4}$ \\ ${ }^{1}$ Research Institute of Water and Environmental Engineering, Universitat Politècnica de València (UPV), Camino de Vera s/n, \\ 46022 Valencia, Spain \\ ${ }_{2}^{2}$ Presas Risk Analysis, Avda. del Puerto 180 1B, 46023 Valencia, Spain \\ ${ }^{3}$ Green Blue Management, Avda. del Puerto 180 1B, 46023 Valencia, Spain \\ ${ }^{4}$ Oliva City Council, Pl. Ajuntament 1, 46780 Oliva, Spain \\ Correspondence to: Jesica Tamara Castillo-Rodríguez (jecasrod@upv.es)
}

Received: 25 February 2016 - Published in Nat. Hazards Earth Syst. Sci. Discuss.: 1 March 2016

Revised: 6 July 2016 - Accepted: 6 July 2016 - Published: 29 July 2016

\begin{abstract}
This article presents a method to incorporate and promote quantitative risk analysis to support local action planning against flooding. The proposed approach aims to provide a framework for local flood risk analysis, combining hazard mapping with vulnerability data to quantify risk in terms of expected annual affected population, potential injuries, number of fatalities, and economic damages. Flood risk is estimated combining GIS data of loads, system response, and consequences and using event tree modelling for risk calculation. The study area is the city of Oliva, located on the eastern coast of Spain. Results from risk modelling have been used to inform local action planning and to assess the benefits of structural and non-structural risk reduction measures. Results show the potential impact on risk reduction of flood defences and improved warning communication schemes through local action planning: societal flood risk (in terms of annual expected affected population) would be reduced up to $51 \%$ by combining both structural and nonstructural measures. In addition, the effect of seasonal population variability is analysed (annual expected affected population ranges from 82 to $107 \%$, compared with the current situation, depending on occupancy rates in hotels and campsites). Results highlight the need for robust and standardized methods for urban flood risk analysis replicability at regional and national scale.
\end{abstract}

\section{Introduction}

Floods are among the most damaging natural disasters in Europe and worldwide. In this paper, the need for improved quantitative flood risk analysis is identified, current and future challenges on flood risk reduction are acknowledged, and a framework for flood risk analysis is presented and applied to a city as an example for enhanced local flood risk management.

\subsection{The need}

In the period 1985-2015, Europe has suffered nearly 481 major flood events, with 3136 fatalities, more than 12 million affected people, and more than USD 123 billion economic losses (Université Catholique de Louvain, 2015). Flood risk assessments for future scenarios in several countries show that risks might rise due to climate or socioeconomic changes. Examples of analyses and projections of future exposure and risk at national scale can be found, e.g. in the Netherlands (Jongman et al., 2014), United Kingdom (Sayers et al., 2015), and Austria (Fuchs et al., 2015). In addition, analyses at European scale can also be found (Barredo, 2009), which show that the increase observed on flood risk is mainly due to socioeconomic shifts. However, future risks are influenced by both climate and socioeconomic projections and these may significantly vary for each region or country. Urban areas concentrate population and economic activities, thus presenting high flood vulnerability. Mediter- 
ranean cities are particularly affected by flooding as they are located next to rivers and in lowland areas and are affected by flood events in ephemeral streams. In many Mediterranean cities, the combination of basin physical characteristics and intense and irregularly distributed rain generates frequent floods.

As an example, the Valencian region in Spain has suffered severe flood events in the last decades (Université Catholique de Louvain, 2015), such as the 1957 Turia river flood (with 77 fatalities) and the 1982 flood from failure of Tous dam (with 43 fatalities and more than 226000 affected people).

As a result of the impact of past flood events and the need for reducing existent flood risk, the European Commission published the Directive 2007/60/EC on 6 November 2007 (European Parliament, 2007), aiming at reducing and managing the risks that floods pose to human health, the environment, cultural heritage, and economic activity. This directive requires all member states to assess risks related to water courses and coastlines, to develop hazard and risk maps, and to apply measures to reduce flood risk.

This directive was transposed into Spanish law by Royal Decree 903/2010, "Flood risk evaluation and management", which requires the definition of all areas with potential flood risk within the territory. This decree establishes the content of hazard and risk maps, along with flood risk management plans at river basin scale.

More particularly, in the Valencian region, the regional government developed PATRICOVA (Territorial Action Plan for Flood Risk Prevention) in 2003, a preventive tool with recommended actions for urban planning and flood risk reduction. Municipalities classified at medium and high flood risk levels are required to develop local action plans for flood risk management (in Spanish, "Planes de Actuación Municipal ante el Riesgo de Inundaciones", herein denoted as PAMRI by its acronym). PATRICOVA has been recently updated in 2015, incorporating new legislation and integrating recent advances in cartography.

Despite recent legislation and work conducted on flood risk management, there is still a need for local flood risk analyses to complete those developed at regional scale, to inform action planning, and to better orientate risk reduction actions at urban scale. In most cases, despite some exemptions found in the literature such as guidance and examples of micro-scale flood risk assessment carried out e.g. in England and Wales (Penning-Rowsell et al., 2013), there is a lack of applications of risk analysis techniques at local scale or the required level of detail to support decision-making on local flood risk reduction and planning.

\subsection{The challenge}

Flood risk management has acquired an important role since the European Floods Directive (Directive 2007/60/EC) and global strategies for flood risk reduction have evolved from focusing mainly on reducing the hazard (structural measures) to more holistic approaches, including the combination of both hazard and impact mitigation.

Different approaches for flood risk analysis can be found in the literature, including societal (Jonkman et al., 2008) and economic risks (Merz et al., 2010), and ranging from local (Marcotullio and McGranahan, 2006) to global scale (Winsemius et al., 2013).

"Think globally, act locally", the famous phrase attributed to René Dubos during the UN Conference on the Human Environment in 1972, emphasizes the importance of scale in dealing with environmental challenges. Unique physical, climatic, and cultural conditions appear at local scale and sitespecific flood risk management is needed.

In the Valencian region, only 18 out of 136 local action plans for flood risk management have been developed and approved up to date. Despite the publication of some recommendations by civil protection on how to perform these plans, local authorities do not have the information, knowhow, or experience of the required flood risk analyses to be developed.

The city of Oliva, located on the eastern coast of Spain, belongs to the group of municipalities within medium to high flood risk levels. Located $70 \mathrm{~km}$ from Valencia, Oliva is affected by pluvial, river, and coastal flooding and it is characterized by a complex and wide-ranging geography (e.g. hills up to 460 m.a.s.l., plains, coastal areas, and wetlands). In addition, there is high seasonal variation in population (with 27127 and 55174 inhabitants of resident and seasonal population, respectively, distributed across $60.1 \mathrm{~km}^{2}$ ).

Twenty-eight years after the largest flood event in modern times in Oliva (accounting for the highest recorded rainfall rate at the Iberian Peninsula with $817 \mathrm{~mm}$ in $24 \mathrm{~h}$ ), local authorities face the challenge of mitigating flood risk through the development and implementation of a local action plan (as required by regional legislation), in line with other existent and ongoing structural measures for flood risk reduction.

Local and regional authorities stand at the front line of reducing the vulnerability of their territory to natural hazards and impacts of climate change (Mayors Adapt, 2015). In this context, quantitative flood risk analysis arises as a helpful tool to support management actions and strategies.

\subsection{The opportunity}

Flood risk is commonly expressed in terms of expected annual damage (in terms of potential affected population, number of fatalities, or economic damage), obtained from the combination of three key components: flooding probability, exposure determinants, and vulnerability of receptors (Klijn et al., 2015). Generally, risk is conceptualized as the multiplication of flood probability and consequences. In this paper, we propose flood risk analysis through the use of risk models, capable of estimating annual risk for different scenarios and performed for a real case study, based on results from flood hazard characterization and consequence estimations. This 
paper aims to present a framework for local flood risk analysis and its application to a real case to show how local flood risk management strategies may benefit from risk analysis. This paper analyses the city of Oliva (Spain) as an example. Although flood hazard mapping is available, a quantitative flood risk analysis had never been performed. The presented study is being used as a basis for developing a local action plan against flood risk.

This "science for policy" paradigm can be considered as a "lighthouse" example for other cities in Spain that are required to develop their corresponding plans. Examples can be found in the literature on examples of the benefits of research for policy and practice for flood risk management (Klijn and Schweckendiek, 2012). The study shows how flood probability, exposure, and vulnerability analyses provide valuable information for the development of a local action plan against flooding, for example by characterizing the impact on risk of improved warning systems and public education campaigns.

\section{Approach}

In this section, the applied framework (including tools and methods) for flood risk analysis is described. This framework for flood risk analysis is based on the method proposed by (Escuder-Bueno et al., 2012), through the use of a risk model which incorporates all information regarding loads, system response, and flood consequences, and adapted to integrate GIS data into risk modelling. Figure 1 shows the flowchart summarizing data, methods, and tools within the presented framework.

Potential applications include local flood risk assessments such as those required by regional and national legislation in Spain after the 2007 European Floods Directive.

Examples of such structured frameworks for flood risk analysis for other hazard types such as flooding from mountain rivers or landslides can be found in the literature (Fell et al., 2008; Mazzorana et al., 2013), as a means to enhance flood risk analysis processes.

The steps of the proposed framework include

- phase I: scope of the case study

- phase II: review of available data

- phase III: study of the system situation and definition of the base case

- phase IV: flood events to be analysed

- phase V: risk model architecture

- phase VI: input data for the risk model

- phase VII: risk calculation

- phase VIII: risk representation

- phase IX: risk evaluation
- phase X: study of risk reduction measures.

\subsection{Phase I: scope of the case study}

The proposed framework aims at estimating flood risk in urban areas in terms of affected population, potential injuries, fatalities, and economic costs resulting from damage to assets and infrastructure. It can be applied to analyse existent risk or to compare different scenarios to evaluate the impact of risk reduction measures.

The level of detail of the required analysis will depend on the scope and scale of decisions for flood risk management.

\subsection{Phase II: review of available data}

Information on hydrologic studies, hydraulic modelling, flood defence response, population, and land use data is required for characterizing loads, system response, and estimating consequences from flooding.

GIS data on flood characteristics (e.g. flood depth, velocity, flooded area) and population and land uses are required to apply the procedure proposed in Fig. 1. In recent years, more detailed and up-to-date GIS-based data are available, thus allowing a more accurate estimation of flood hazard, exposure, and vulnerability.

\subsection{Phase III: study of the system situation: definition of the base case}

The base case corresponds with the benchmark scenario. The benchmark scenario should represent the system situation, incorporating existing structural and non-structural measure for flood risk reduction and system characteristics in terms of exposure and vulnerability. Therefore, it is of high importance to define not only the benchmark scenario but also those after implementing planned risk mitigation actions, to be compared with the base case. Examples of scenario building processes for flood risk analysis from mountain rivers are found in Mazzorana et al. $(2012,2013)$.

\subsection{Phase IV: flood events to be analysed}

The range of all potential flood events should be considered, obtained from hydrologic studies and analysed through hydraulic simulations to characterize system response and flood characteristics.

Flood defence reliability should be incorporated, when possible, into hydraulic modelling to analyse the existent protection level and the impact on flood characteristics of their performance (failure and non-failure cases of flood protection infrastructure).

This range will be divided into intervals, as shown in Fig. 2, to incorporate data on flood hazard probabilities into the risk model performed in phase V. Each flood event interval is characterized by a representative annual exceedance probability (AEP). 


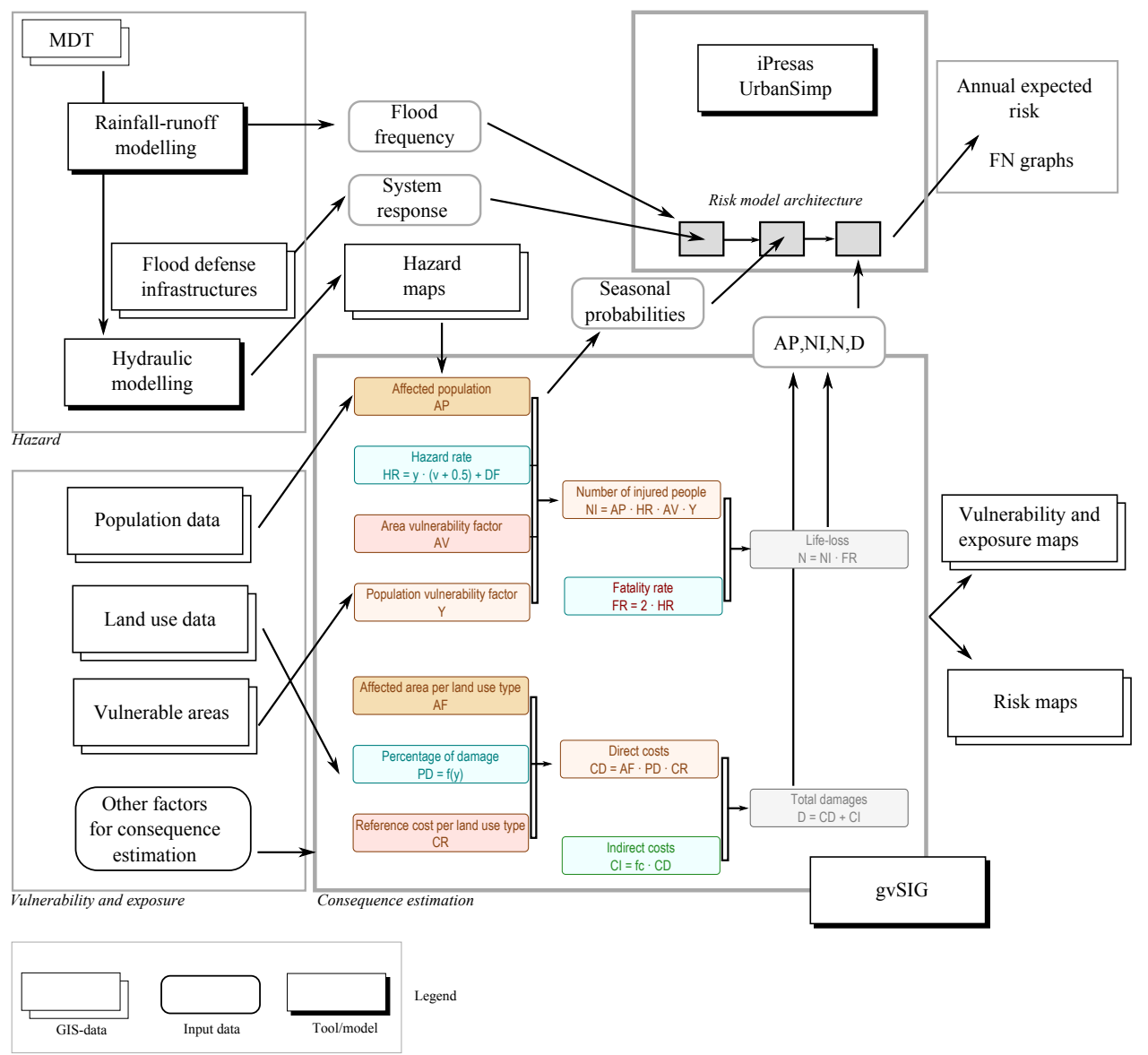

Figure 1. Flowchart of data and models.

\subsection{Phase V: risk model architecture}

The use of risk models provides a logic and mathematically rigorous framework for compiling information of the system to estimate flood risk (Castillo-Rodriguez et al., 2014).

The risk model can be represented by an influence diagram composed by nodes and connectors (Serrano-Lombillo et al., 2011). Nodes include information on loads (e.g. annualized probabilities of flood events), system response (failure probabilities of flood defence infrastructures, e.g. dam or levee breach), or consequences (e.g. results from consequence estimations in terms of affected population or economic damages).

In this paper, two generic schemes for defining the risk model architecture are proposed and shown in Fig. 3. The first scheme (model "a") can be used for analysing flood risk for urban areas affected by river flooding from non-regulated systems. The second scheme (model "b") should be used when potential failure of a flood defence (e.g. a dam) is incorporated into the analysis.

These two generic influence diagrams are an adapted version of those proposed by Castillo-Rodriguez et al. (2014).

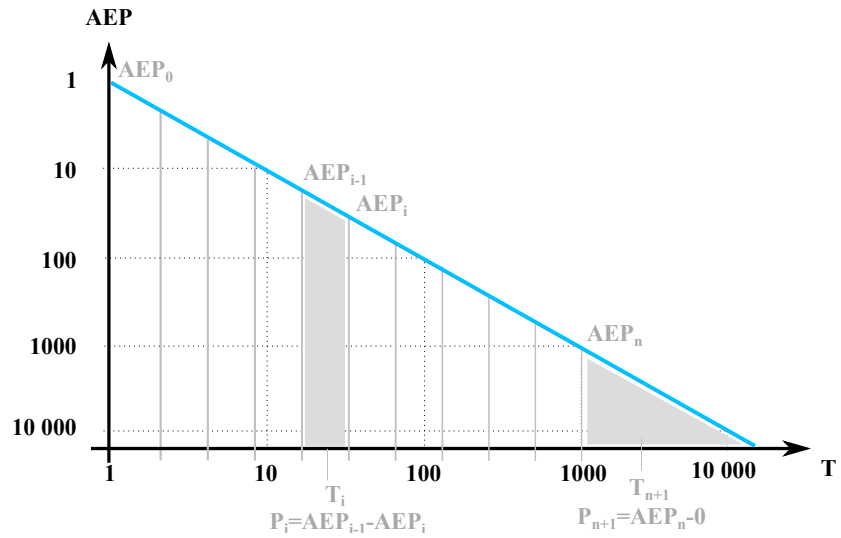

Figure 2. Generic division of the analysed range of flood events.

These schemes allow one to include the analysis of societal risk in terms of affected population, potential injuries, fatalities and economic costs due to damages from flooding (assets, infrastructure, and services). 


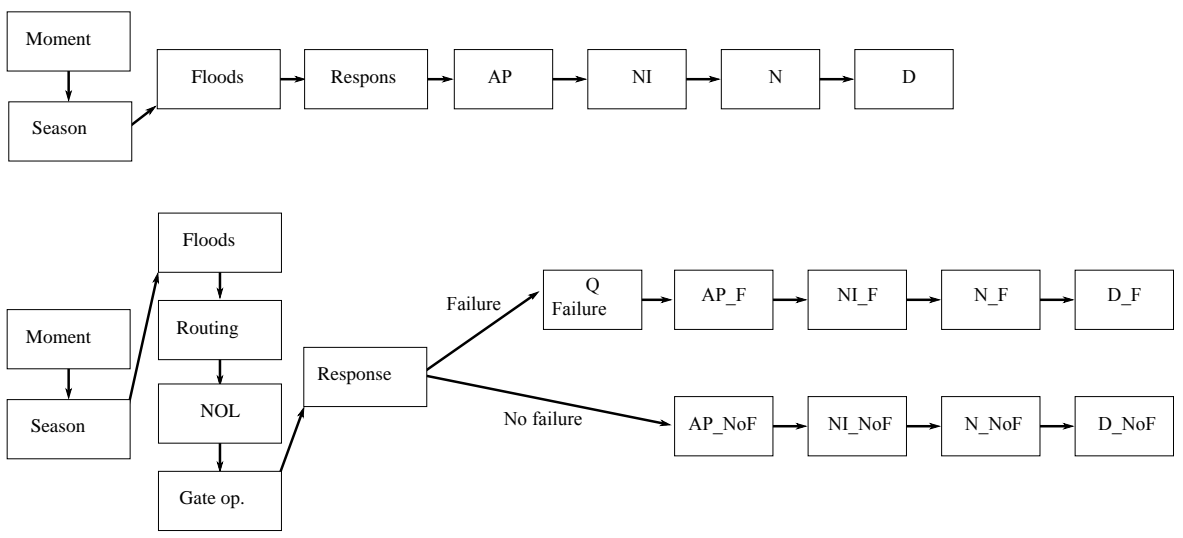

Figure 3. Generic risk model architecture: non-regulated river system (a) and regulated river system (b).

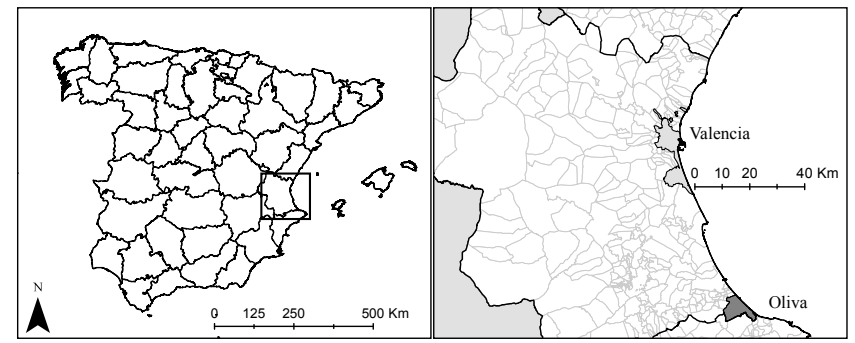

Figure 4. Location of the case study area at national (left) and regional (right) scale.

For the first influence diagram (model "a"), proposed to analyse flood risk in non-regulated systems, the following nodes are considered.

- Moment: this node includes information on probabilities for different time periods during the day (i.e. the probability of being during the day or at night). It can be used to later incorporate daily variability on potential consequences (e.g. affected population in industrial areas might change depending on the moment of the day).

- Season: this node includes information on probabilities for different seasonal periods during the year (i.e. the probability of being in summer or winter season). It can be used to later incorporate seasonal variability on potential consequences (e.g. affected population in urban areas might change when resident or potential population during summer is considered).

- Flood events: this node includes information on probabilities for different flood events. A range of flood events is established, defined by minimum and maximum return periods. This range is divided into a number of intervals (e.g. 10, 20). Figure 2 shows how the range of plausible flood events is divided into intervals for risk calculations. These intervals are equally spaced in logarithmic scale along the given range of return periods.
Each interval is represented by an AEP, obtained by deducting AEP values of low and high interval limits. The example shows a range from 1- to 1000-year flood events into 10 intervals. An additional interval is added to include flood events that exceed the 1000-year return period.

- System response: this node includes information on system response (e.g. peak flow river discharges).

- Affected population, number of injured people, potential fatalities, and economic costs: these nodes include information on consequence estimation in terms of affected population (AP), injuries (NI), fatalities (N), and economic damages in the urban area (D) respectively. Estimations for different flood events are obtained and incorporated into the risk model in each node.

For the second influence diagram (model "b"), proposed to analyse flood risk in a regulated river system with a dam, the following nodes are considered.

- Moment, season, and flood events: these nodes are equivalent to the aforementioned described for the first influence diagram.

- Normal operating level (NOL): this node includes the water level at the reservoir in normal situation. For simplicity, it is assumed that this level is constant.

- Gate operability: this node includes probabilities for each possible combination of gate operability (number of gates functioning correctly for flood routing when the flood arrives) for dams with controlled outlet works.

- Routing: this node refers to results from the technique used to estimate evolution of water levels at river course and reservoirs during the flood event, based on initial conditions (water level when the flood arrives). Results from flood routing are included in this node for each flood event and gate operability combination. Two 
outcomes from flood routing analysis are required: the maximum water pool level at the reservoir and resulting peak flow discharge through outlet works for each combination.

- System response: for each load combination (represented by a maximum water pool level from flood routing), this node is used to consider two possible situations: failure and non-failure of the flood defence system, with complementary conditional probabilities of occurrence for each load combination. Hence, two branches emerge from this node to consider both options.

- Failure and non-failure hydrographs: these nodes include information on peak flow discharges resulting from flood defense failure or non-failure cases (i.e. peak flow discharges from flood routing).

- Affected population, number of injured people, potential fatalities, and economic costs: these nodes include information on consequence estimation in terms of affected population, injuries, fatalities, and economic damages in the urban area for flood events resulting from flood defense failure (upper branch) and nonfailure cases (lower branch).

\subsection{Phase VI: input data for the risk model}

A GIS-based tool is proposed for input data processing. The tool, named gvSIG Desktop (www.gvsig.com), is an opensource software, GNU/GPL license, with free use, distribution, study, and improvement. Recently, gvSIG has been graduated as an OSGeo project (Open Source Geospatial Foundation). This GIS software tool was first developed by the regional government of the Valencian Autonomous Region (to be widely implemented in their regional and local systems) and now is further developed and promoted by the gvSIG Association.

The use of other available GIS tools can be applied within this framework (e.g. qGIS). In this paper, gvSIG has been applied since it is being used by local governments in Spain.

In this paper, the procedure shown in Fig. 1 is proposed to integrate GIS data into the risk model in phase VII. This procedure shows the required steps to estimate flood consequences and to provide input data for the risk model in terms of affected population, potential injuries, and fatalities and damage costs at local scale. This GIS-based procedure aims at boosting implementation of risk-informed local action plans through standardized consequence estimation and risk calculation.

The information required includes the following.

- Hydrological and hydraulic modelling: flood characteristics should be estimated for each cell on the map representing the study area for different floods (a range of flood events with return periods up to, at least, 500-year is recommended). Two maps are required showing inundation depths and flow velocities for each cell.

- Consequence estimation: several types of consequences per cell on the map are obtained. The impacts are then aggregated at municipality scale. The impacts include population exposed to flooding, injuries, potential fatalities, and economic damages.

- Affected population should be obtained using census data (resident and seasonal population) and information on occupancy rates in hotels, campsites, etc. Accuracy and precision on population distribution is of high importance to enhance risk estimates. Detailed knowledge of population distribution and variability will help to better define potential scenarios (day/night, seasonal and/or spatial variability).

- The life-loss estimation method proposed by MAGRAMA (Spanish Ministry of Agriculture, Food, and Environment) for developing risk analysis at river basin scale is used. This method is based on the methodology proposed by DEFRA (Department for Environment, Food, and Rural Affairs). Recent flood risk analyses have been conducted in Spain by applying this methodology, as for example in the Ebro River basin (PREEMPT project "Policy-relevant assessment of socioeconomic effects of droughts and floods"). For a detailed description on the method for estimating potential fatalities, the reader is referred to DEFRA (2006).

- Economic damage estimation is based on the method used in PATRICOVA (Generalitat Valenciana, 2015). Potential direct economic damage costs are obtained using information on land use categories to define asset values and applying a depth-damage function, which estimates the expected damage for a given inundation depth.

- Risk modelling: input data on floods (exceedance probabilities), river discharge (system response), and estimated consequences (aggregated outcomes at municipality scale from GIS data) are incorporated into the risk model to estimate societal and economic risk in terms of annual expected impacts.

Table 1 shows a summary of most relevant variables and data sources for flood risk analysis based on the presented framework in Fig. 1.

\subsection{Phase VII: risk calculation}

Aggregated data on consequence estimation per flood event, from phase VI, are incorporated into the risk model proposed in phase V. The iPresas UrbanSimp (www.ipresas.com) software tool is used for risk calculation and modelling. This 
Table 1. Summary table of main variables and outcomes used in the presented framework for flood risk analysis.

\begin{tabular}{|c|c|c|c|}
\hline Risk component & Main variables & Data source & Risk outcome \\
\hline \multirow[t]{2}{*}{ Flood probability } & $\begin{array}{l}\text { Annual exceedance } \\
\text { probability (AEP) }\end{array}$ & Hydrologic studies & \multirow{4}{*}{$\begin{array}{l}\text { Annual expected affected } \\
\text { population (AEAP) } \\
\text { Annual expected number of } \\
\text { injured people (AENI) } \\
\text { Annual expected number of } \\
\text { potential fatalities (AEN) } \\
\text { Annual expected economic } \\
\text { damages (AED) }\end{array}$} \\
\hline & $\begin{array}{l}\text { Failure probabilities } \\
\text { (system response) }\end{array}$ & System reliability analysis & \\
\hline Exposure & $\begin{array}{l}\text { Flood depth (y) } \\
\text { Flow velocity (v) } \\
\text { Flooded areas (AF) } \\
\text { Debris factor (DF) } \\
\text { Hazard ratings (HR) }\end{array}$ & Hydraulic modelling & \\
\hline Vulnerability & $\begin{array}{l}\text { Area vulnerability (AV) } \\
\text { People vulnerability (Y) } \\
\text { Affected population (AP) } \\
\text { Percent of damages (PD) } \\
\text { Reference costs (CR) } \\
\text { Number of injured people (NI) } \\
\text { Number of potential fatalities (N) } \\
\text { Economic damages (D) }\end{array}$ & $\begin{array}{l}\text { Land use distribution } \\
\text { Census data distribution } \\
\text { Consequence analysis }\end{array}$ & \\
\hline
\end{tabular}

tool is a simplified version of iPresas Calc, first developed by the Polytechnic University of Valencia (UPV) and now by iPresas Risk Analysis (spin-off company of UPV). iPresas Calc is a software tool that combines input data on flood hazard and impact to obtain expected annual risk (SerranoLombillo et al., 2011). Risk, in terms of expected annual societal or economic risk, is calculated by developing the event tree that considers all combinations of events that may lead to flooding.

In this paper, flood risk is defined as the combination of the probability of a damaging flood event and potential consequences (Gouldby and Samuels, 2005; Schanze, 2006). Risk is estimated as the expected annual average damage of flooding in terms of societal or economic consequences. Hence, risk is obtained in terms of expected annual population affected (EAPA), number of injuries (EANI), fatalities (EAF), and damage costs (EAD). The iPresas UrbanSimp software tool estimates risk by developing the event tree that includes all combinations of flood events, system response, and related consequences.

Although there are examples of flood risk analysis approaches which include economic, social, and environmental risks (Meyer et al., 2009), conducting a quantitative analysis of environmental risks was out of scope of this research work. In contrast, societal risk is considered based on a threefold perspective: potential affected population, injured, and fatalities.

\subsection{Phase VIII: risk representation}

Risk can be represented in F-N curves. The area under the curve is the annual expected number of fatalities, where the horizontal axis represents the level of consequences (e.g. number of fatalities, denoted as N) and the vertical axis represents the annual cumulative probability of exceedance $(\mathrm{F})$ of each level of consequences.

Other type of consequences can be represented. These curves are then called F-D or F-AP, by representing economic costs due to damages (D) or affected population (AP) respectively.

\subsection{Phase IX: risk evaluation}

Risk outcomes can be compared with tolerability recommendations (when available), thus enabling one to analyse whether risk reduction measures are justified or not when evaluated in contrast with proposed criteria. Generalized frameworks for risk evaluation can be found in the literature (UK Health and Safety Executive, 2001). However, there still is a lack of tolerability criteria applied at local scale, although some recent examples can be found (Miller et al., 2015).

Tolerability recommendations for individual and societal risk have been published by several authors and organizations (Vrijling, 2001). As an example, the United States Bureau of Reclamation suggests a limit of 0.01 fatalities per year for annualized societal risk when analysing incremental risk from flooding due to dam failure (Hennig et al., 1997). However, this limit, proposed for analysing incremental risks 
(attributed to the failure of the infrastructure), may not be applied when analysing flood risks in total terms (due to all potential flood events from both failure and non-failure cases).

\subsection{Phase X: study of risk reduction measures}

Once risk is obtained for the base case, other scenarios can be analysed to evaluate the impact of risk reduction measures. New input data on loads, system response, or consequences should be required and incorporated into the risk model. Risk outcomes for the new scenario are then compared with results for the base case.

Regarding evaluation of risk reduction measures, approaches such as cost-benefit analysis (CBA) and multicriteria analysis (MCA) are commonly used for analysing investment projects, required by law or promoted through guidelines (EC, 2014). In contrast to CBA, which is legally prescribed in some countries (for example in the Netherlands or the United Kingdom), MCA is not widely established, although some examples can be found. For example, project selection for public works in Italy and acquisition of dataprocessing equipment or consulting services by public administration in Spain have to be conducted based on MCA (Gamper and Turcanu, 2007).

In dam safety management, the use of risk indicators that consider efficiency and equity principles is common, evaluating societal and economic risk reduction and costs of measures. The adjusted cost per statistical life saved (ACSLS) indicator is commonly used for evaluating dam risk reduction measures (Morales-Torres et al., 2016).

\section{Case study analysis}

An example of how the framework described in Sect.2 can be applied is included in this section. The results have been used to guide the development and implementation of a local action plan for flood risk management.

\subsection{Phase I: scope of the case study}

The municipality of Oliva is located on the eastern coast of Spain (Fig. 4), has about 27127 inhabitants (distributed in several urbanized areas) and covers a total area of $60.1 \mathrm{~km}^{2}$.

The heaviest daily precipitations historically observed in Spain concentrate mainly on the coastal Mediterranean zone. Indeed, Oliva accounts for the most extreme daily precipitation record in the Iberian Peninsula with $817 \mathrm{~mm}$ on 3 November 1987 (Ramis et al., 2013).

The mean annual precipitation reaches $850 \mathrm{~mm}$. Flood events concentrate mainly during the rainy season from $\mathrm{Au}$ gust to November. Table 2 shows a summary of most relevant flood events in Oliva.

The system is characterized by multiple river courses and brooks, with complex interconnections and a varying topography, including lowland areas and hills up to $460 \mathrm{~m}$ a.s.l.
A dam is currently under construction in Rambla Gallinera river course (a $62.5 \mathrm{~m}$ high concrete gravity dam, with a total reservoir capacity of $6.13 \mathrm{hm}^{3}$ at dam crest level). Civil works started in 2010 (including river embankments, diversion of secondary brooks to Rambla Gallinera river course, and dam construction), but they are not finished yet. The dam will provide flood protection up to a return period of 10 years (Hijós Bitrián et al., 2010) and significant reduction on the peak flow discharges at this river course up to $56 \%$ (50-year flood event). Discharges are also attenuated for floods with higher return periods, with a minimum reduction of $8.6 \%$ (5000-year flood).

Oliva is composed by several urbanized areas distributed within the municipality. The main area is located in the north-western part, concentrating $84.6 \%$ residential population (59.6\% seasonal population). However, other areas located along the coast are relevant as population may increase by 23 times in some districts.

The selection of this study area is based on several reasons. First, the intensity and frequency of past flood events in the region are relevant. Second, good-quality and up-todate data are available on hazard, population, and land use mapping. Additionally, the impact of structural and nonstructural flood risk reduction measures has not been quantified so far. Finally, local authorities are currently involved in the process of developing the Municipal Action Plan against Flood Risk (denoted as PAMRI).

\subsection{Phase II: review of available data}

Population and land use data are GIS based. These data, provided by local government, are based on a yearly survey promoted by the regional government for all municipalities with less than 50000 inhabitants (hereafter EIEL database, by its acronym in Spanish). The municipality is distributed in 9324 and 16131 parcels of urban and rural land respectively.

The EIEL database includes resident and seasonal population: "resident population" is obtained from census data and "seasonal population" is estimated from demographic trends observed in the last years during the summer season. It includes both resident and occasional population (but does not include hotel and campsite occupancy). For this analysis, the summer period ranges from mid-April to mid-September.

This database is completed with observations during site visits and other inputs from local authorities.

\subsection{Phase III: study of the system situation: definition of the base case}

Four scenarios are considered for flood risk analysis as follows.

- Current situation (scenario 0): this scenario represents the current situation of the system and it is used for benchmarking (to compare with results of scenarios 1 to 3 ). This scenario is considered as the base case. 
Table 2. Summary of recent (most relevant) flood events for the case study.

\begin{tabular}{lccccccc}
\hline Date (dd-mm-yуyy) & $03-11-1987$ & $04-12-1997$ & $29-11-1972$ & $18-06-1997$ & $30-03-2002$ & $11-09-1996$ & $05-05-2002$ \\
\hline Precipitation in 24 h (mm) & 817 & 378 & 354 & 288 & 220 & 197 & 188 \\
\hline
\end{tabular}

Table 3. Simulated peak flow discharges per river course (SOBEK model) $\left(\mathrm{m}^{3} \mathrm{~s}^{-1}\right)$.

\begin{tabular}{l|rrr|rrr}
\hline & $\begin{array}{c}\text { Current situation } \\
\text { (scenario 0) }\end{array}$ & \multicolumn{3}{c}{$\begin{array}{c}\text { Structural measures } \\
\text { (scenario 1) }\end{array}$} \\
\hline & \multicolumn{5}{c}{ Return period (years) } \\
\hline River course & 25 & 100 & 500 & 25 & 100 & 500 \\
\hline Piles & 84 & 153 & 247 & 84 & 153 & 247 \\
Fonts & 54 & 107 & 186 & 54 & 107 & 186 \\
Algepsar & 7 & 11 & 23 & 7 & 11 & 23 \\
Frares & 4 & 7 & 16 & 4 & 7 & 16 \\
Alfadalín & 21 & 34 & 82 & 21 & 34 & 82 \\
Cementeri & 2 & 4 & 8 & 2 & 4 & 8 \\
Gallinera & 282 & 462 & 1025 & 182 & 284 & 829 \\
Benirrama & 16 & 28 & 63 & 16 & 28 & 63 \\
Bullent & 102 & 173 & 399 & 102 & 173 & 399 \\
Molinell & 84 & 146 & 318 & 84 & 146 & 318 \\
\hline
\end{tabular}

- Implementation of structural measures (scenario 1): this scenario represents the situation after implementing structural measures for flood risk reduction, including dam construction. Differences in peak flow discharges in Rambla Gallinera are shown in Table 3 (e.g. from 282 to $182 \mathrm{~m}^{3} \mathrm{~s}^{-1}$ for a 25 -year flood event).

- Implementation of a local action plan (scenario 2): this scenario represents the situation after implementing a local action plan against flooding (PAMRI), which includes improved warning and communication schemes, public education campaigns and training of all actors involved in emergency management.

- Implementation of both local action plan and structural measures (scenario 3): this scenario represents the situation after implementing both structural and nonstructural measures.

\subsection{Phase IV: flood events to be analysed}

The regional plan PATRICOVA defines six flood hazard levels (denoted from NP1 to NP6) based on probability of flood occurrence (return periods of 25, 100, or 500 years) and inundation depth (above/below $0.8 \mathrm{~m}$ ). Flood hazard levels in Oliva were obtained in 2002 from an inundation study at regional scale and reviewed in 2013 (adding a new level to identify geomorphological hazards). However, resolution of GIS data used for the regional plan is too low (scale was $1: 50000$ in 2002 and $1: 25000$ for the updated version in
2013). In addition, the recent review did not consider new and ongoing structural actions for flood risk reduction.

In this paper, we used inundation data from a hydraulic model developed in 2010 by ACUAMED (Aguas de las Cuencas Mediterráneas S.A., public corporation and instrument of the Ministry of Agriculture, Food, and Environment for Mediterranean River Basin Development Programme) and updated by TYPSA (consulting firm) in 2012 with a DEM (digital elevation model) with a $5 \mathrm{~m}$ horizontal resolution derived from lidar (light detection and ranging or laser imaging, detection, and ranging) and corrected by site measures. However, only three flood events were modelled (return periods of 25, 100, and 500 years). Table 3 shows peak flow discharges for two scenarios: current situation (scenario 0) and after implementing structural flood risk reduction measures including the dam under construction (scenario 1$)$.

\subsection{Phase V: risk model architecture}

For this case study, the risk model architecture shown in Fig. 5 is used. Dam failure flood events are not modelled. Flood characteristics after dam construction (scenario 1) are considered based on flood routing analysis.

In order to determine societal or economic risk, the choice of a wide range of flood events is important. However, availability covers 25 to 500 years. Vulnerability was estimated for 25-, 100-, and 500-year flood events, based on the proposed framework in Sect. 2.

Given the discrete set of flood events, the range of plausible flood events is divided into 20 intervals, obtaining expected damage for each interval by interpolating input data for the three available events.

The impact of a 1-year flood event is assumed to be 0 for the current situation (scenario 0). A flood protection level of 10 years is considered for scenarios 1 and 3 .

\subsection{Phase VI: input data for the risk model}

Concerning flood probability estimation, inundation maps with results from a 2-D hydraulic model in SOBEK (a modelling suite developed by Deltares), with runoff rates from HEC-HMS (developed by the US Army Corps of Engineers, USACE) are used. These maps are raster based, with a spatial resolution of $20 \mathrm{~m} \times 20 \mathrm{~m}$. Data on flood depth and velocity are available at each grid cell for the three return periods. Inundation map for the 500-year flood event and hazard level map as defined by PATRICOVA are included in supplemen- 


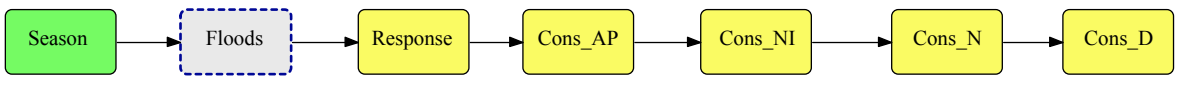

Figure 5. Risk model architecture for the case study of Oliva using iPresas UrbanSimp software tool.

Table 4. Summary of land use types for the case study (non-urbanized areas were also analysed but not included in this table).

\begin{tabular}{lrrr}
\hline Land use type & Area $\left(\mathrm{m}^{2}\right)$ & Percentage of urban area $(\%)$ & Reference value $\left(\mathrm{EUR} \mathrm{m}^{-2}\right)$ \\
\hline Commercial & 19348 & $0.4 \%$ & 34.55 \\
Cultural & 47916 & $1.0 \%$ & 34.55 \\
Health services & 23672 & $0.5 \%$ & 34.55 \\
Industrial & 687372 & $14.9 \%$ & 11.25 \\
Institutional & 17288 & $0.4 \%$ & 34.55 \\
Office building & 14573 & $0.3 \%$ & 34.55 \\
Other uses & 131249 & $2.8 \%$ & 0 \\
Residential & 3043656 & $66.0 \%$ & 68.7 \\
Restaurants & 8512 & $0.2 \%$ & 34.55 \\
Sports facilities & 614618 & $13.3 \%$ & 34.55 \\
Warehouse & 58112 & $1.3 \%$ & 11.25 \\
\hline
\end{tabular}



Figure 6. Hazard level map for scenario 0 (current situation).

tary material for the current situation. The hazard level map for the current situation is also shown in Fig. 6.

Results from hazard analysis show that $10 \%$ of resident population is located in low-frequency flood areas, against a $15 \%$ of resident population located in high-frequency areas (25-year flood event). Around 14000 are located in NP1 areas, "high frequency-high flood depth" category (flood depth greater than $0.8 \mathrm{~m}$ for the 25 -year flood event).

Regarding consequence estimation, the municipality is divided into urban and rural parcel sub-areas and information from EIEL database is available in GIS format.

The number of resident and potential (seasonal) inhabitants in each parcel is obtained by multiplying the number of registered households and the corresponding density value (inhabitants/household). In addition, population in camping areas and hotels is considered based on the maximum capacity and hotel occupancy rates in the Valencian region (2013 Database from National Statistics Institute). These rates are assumed to be, on average, 35 and $75 \%$ in winter and summer seasons respectively. Table 4 summarizes the results of affected population. A 500 -year flood has a $0.2 \%$ probability of occurring in any given year and affect cause roughly 22890 people during summer season for scenario 0 .

Estimation of potential life loss is based on the method proposed by DEFRA (DEFRA, 2006). The number of fatalities is a function of the number of injuries and the hazard rating, where the number of injuries is estimated by combining the following factors:

- number of people within the hazard zone;

- hazard rating, which combines flood characteristics (flood depth, flow velocity, and debris factor);

- area vulnerability, the function of effectiveness of flood warning, speed of onset of flooding, and nature of area (including types of buildings); and

- people vulnerability, the function of presence of people who are very old and/or infirm/disabled/long-term sick.

The following assumptions for the case study analysis are considered:

- an average debris factor (DF) equal to 0.5 is used to estimate hazard rates;

- a vulnerability area factor (AV) equal to 6,7 , and 8 is used for multi-storey buildings, residential areas, and campsites respectively;

- a population vulnerability factor $(Y)$ of 0.2 is used based on census data (i.e. percentage of population aged 65 years and over). 
We calculated the potential direct economic damage using information on land use classes (a summary is included in Table 5), reference asset values, and a generic depth-damage function (denoted as CS in Fig. 8), which estimates the expected damage for a given inundation depth. Direct costs are obtained by multiplying percent of damage (based on flood depth), flooded area (in $\mathrm{m}^{2}$ ), and reference cost (in monetary terms per $\mathrm{m}^{2}$ ).

It is essential to adjust asset values to the regional economic situation and property characteristics (Jongman et al., 2012). Therefore, asset values and a generic stage damage function used in regional studies for flood risk planning are considered in this case study (Generalitat Valenciana, 2015). A sensitivity analysis has been included to analyse their impact on results. Different stage damage functions would impact on consequence estimation results as later described in Sect. 4.

Other direct costs such as destruction of vehicles, damage to infrastructure, and livestock or business interruption are not considered. Indirect costs are considered based on factors used by regional planning (Generalitat (Generalitat Valenciana, 2015), set as $7 \%$ of direct costs for the city of includes aspects such as population, employment, and number of households within the urban area). Total costs are obtained by adding direct and indirect costs for each affected parcel.

Table 6 summarizes the results of consequence estimation. A 500-year flood could cause roughly nine potential fatalities and EUR 52 million for scenario 0.

The impact of implementing a local action plan against flooding (PAMRI) is analysed based on the following changes on consequence estimation from improved warning systems and communication schemes.

- A lower rate of AV is considered. Hence, values change to $\mathrm{AV}=5$ in urbanized areas with multi-storey buildings, $\mathrm{AV}=6$ in residential areas, and $\mathrm{AV}=7$ in campsites.

- A reduction on economic damages is assumed based on damage avoided when a warning lead time of at least $2 \mathrm{~h}$ is provided. For a $80 \%$ rate of warning coverage (proportion of covered properties), $100 \%$ rate of service effectiveness (proportion of flooded serviced properties that were sent a timely, accurate, and reliable flood warning), $80 \%$ rate of availability (proportion of flooded services properties that received warning), $85 \%$ rate for ability (proportion of residents able to understand and respond to such a warning), and $85 \%$ rate for effective action (proportion willing to take effective action or which have actually taken effective action), a percentage of damage reduction of $18 \%$ is assumed for flood depths below 1.2 m (Parker et al., 2005).

\subsection{Phase VII: risk calculation}

The iPresas UrbanSimp software tool is used to estimate risk by developing the event tree that includes all combinations of flood events, system response, and related consequences.

Table 6 shows results in terms of expected annual population affected (AEAP), number of injuries (AENI), fatalities (AEF), and damage (AED). Risk outcomes for the current situation show societal risk levels up to 2370 of annual expected affected population and 0.56 fatalities per year. Considerable risk reduction can be achieved by implementing planned structural measures (scenario 1); thus societal risk would be reduced to 1168 inhabitants per year (AEAP) and 0.28 fatalities per year (AEF). Affected population remains equal after implementing local action planning (scenario 2) but societal risk in terms of potential fatalities would be reduced to 0.48 fatalities per year.

In addition, results reflect the combined effect of both structural and non-structural measures (scenario 3). Societal risk after dam construction and implementation of the local action plan might change from 0.56 to 0.24 fatalities per year. Economic risk in terms of annual expected damages would vary from 6.11 to EUR 1.89 million $\mathrm{yr}^{-1}$.

It is noted that at this stage, only direct benefits (such as the reduction in flood damage and improved warning systems) are included in the analysis of the impact of implementing a local action plan. Other benefits such as improved risk awareness or reduction on economic damages to vehicles and local businesses could be considered in future analyses.

\subsection{Phase VIII: risk representation}

Figure 7 shows F-AP, F-N, and F-D curves for all scenarios. The first graph depicts the cumulative annual exceedance probability $(\mathrm{F})$ of each level of potential affected population (AP). Results show that there is a probability of $10^{-2}$ of exceeding 8300 affected people due to flooding for the scenario with structural measures. This value is higher when considering the current situation, with approx. 11300 affected people for the same probability. The second graph depicts the cumulative annual exceedance probability $(\mathrm{F})$ of each level of potential fatalities $(\mathrm{N})$. Results show that there is a probability of $10^{-2}$ of exceeding three fatalities for the current situation (scenario 0). This value decreases after implementing structural measures (scenario 1) to approx. 2 and up to 1.6 for combined structural and non-structural measures (scenario 3). The third graph shows potential economic damages (D) with a probability of $10^{-2}$ of exceeding EUR 28 million for the current situation (scenario 0). This value might decrease up to approx. EUR 17 million after implementing combined structural and non-structural measures (scenario 3).

Finally, results from risk analysis were represented in different hazard and risk maps to support local action planning against flood risk. Recommendations published by the 
Table 5. Estimated impact per scenario and flood event.

\begin{tabular}{|c|c|c|c|c|c|c|c|c|c|}
\hline \multirow{2}{*}{ Season } & \multirow[t]{2}{*}{ Return period (years) } & \multicolumn{4}{|c|}{ Current situation (scenario 0) } & \multicolumn{4}{|c|}{ Structural measures (scenario 1) } \\
\hline & & AP & NI & $\mathrm{N}$ & D (million EUR) & AP & NI & $\mathrm{N}$ & $\mathrm{D}$ (million EUR) \\
\hline \multirow[t]{3}{*}{ Summer (seasonal population) } & 25 & 7795 & 85 & 2 & 10.86 & 5596 & 59 & 1 & 5.27 \\
\hline & 100 & 13269 & 158 & 3 & 22.20 & 9850 & 109 & 2 & 12.15 \\
\hline & 500 & 22890 & 341 & 9 & 52.03 & 18754 & 270 & 7 & 42.39 \\
\hline \multirow[t]{5}{*}{ Winter (resident population) } & 25 & 1873 & 25 & 1 & 10.86 & 1572 & 22 & 0 & 5.27 \\
\hline & 100 & 3428 & 51 & 1 & 22.20 & 2539 & 35 & 1 & 12.15 \\
\hline & 500 & 6282 & 110 & 3 & 52.03 & 4497 & 80 & 2 & 42.39 \\
\hline & Return period (years) & \multicolumn{4}{|c|}{ Local action plan (scenario 2) } & \multicolumn{4}{|c|}{$\begin{array}{l}\text { Structural measures and local } \\
\text { action plan (scenario 3) }\end{array}$} \\
\hline & & AP & NI & $\mathrm{N}$ & D (million EUR) & $\mathrm{AP}$ & NI & $\mathrm{N}$ & $\mathrm{D}$ (million EUR) \\
\hline \multirow[t]{3}{*}{ Summer (seasonal population) } & 25 & 7795 & 73 & 1 & 9.91 & 5596 & 51 & 1 & 4.73 \\
\hline & 100 & 13269 & 136 & 3 & 20.26 & 9850 & 94 & 2 & 10.95 \\
\hline & 500 & 22890 & 293 & 8 & 47.61 & 18754 & 232 & 6 & 38.92 \\
\hline \multirow[t]{3}{*}{ Winter (resident population) } & 25 & 1873 & 22 & 0 & 9.91 & 1572 & 19 & 0 & 4.73 \\
\hline & 100 & 3428 & 44 & 1 & 20.26 & 2539 & 30 & 1 & 10.95 \\
\hline & 500 & 6282 & 95 & 3 & 47.61 & 4497 & 69 & 2 & 38.92 \\
\hline
\end{tabular}

Note: AP is affected population; NI is the number of injured people; $\mathrm{N}$ is fatalities; $\mathrm{D}$ is damage costs in million EUR.

Table 6. Results from risk model per scenarios CS, BC, and effect of local action plan.

\begin{tabular}{|c|c|c|c|c|}
\hline & $\begin{array}{l}\text { Current situation } \\
\text { (scenario 0) }\end{array}$ & $\begin{array}{l}\text { Structural measures } \\
\text { (scenario 1) }\end{array}$ & $\begin{array}{l}\text { Local action plan } \\
\text { (scenario 2) }\end{array}$ & $\begin{array}{l}\text { Structural measures and } \\
\text { local action plan (scenario 3) }\end{array}$ \\
\hline $\begin{array}{l}\text { Societal risk (AEAP) } \\
{\left[\text { inhabitants } \mathrm{yr}^{-1}\right]}\end{array}$ & 2370 & 1168 & 2370 & 1168 \\
\hline $\begin{array}{l}\text { Societal risk (AENI) } \\
\text { [injured inhabitants } \mathrm{yr}^{-1} \text { ] }\end{array}$ & 28 & 21 & 24 & 18 \\
\hline $\begin{array}{l}\text { Societal risk (AEN) } \\
{\left[\text { fatalities } \mathrm{yr}^{-1}\right]}\end{array}$ & 0.56 & 0.28 & 0.48 & 0.24 \\
\hline $\begin{array}{l}\text { Economic risk (AED) } \\
{\left[\text { million EUR } \mathrm{yr}^{-1}\right]}\end{array}$ & 6.11 & 2.10 & 5.57 & 1.89 \\
\hline
\end{tabular}

Note: AE is annual expected; AP is affected population; NI is number of injured people; $\mathrm{N}$ is fatalities; $\mathrm{D}$ is damage costs.

RISKMAP project (Fuchs et al., 2009; Meyer et al., 2012) have been considered for elaborating these maps. An example is provided as Supplement to this paper (affected population for the 500-year flood event for the current situation).

\subsection{Phase IX: risk evaluation}

Tolerability recommendations are not considered for this case study since there are no proposed criteria or guidelines at regional or national level in Spain.

\subsection{Phase X: study of risk reduction measures}

The ACSLS indicator is obtained to evaluate cost-efficiency of analysed measures. Table 7 shows implementation, maintenance, and annualized costs for considered measures (local action plan and structural measures including dam construction). Results show that any of these measures would be justi- fied in terms of efficiency on risk reduction since results show negative values (reduction of economic risk is higher than annualized costs). After implementing the local action plan (lowest ACSLS value), the resulting ACSLS indicator still remains negative when risks before and after implementing structural measures are compared, thus supporting the decision of also implementing planned structural measures.

\section{Sensitivity analysis}

The effect on societal and economic risk of several factors has been assessed in this study. Input data for the risk model have been modified and risk estimations obtained for each case. 
Table 7. Results from evaluation of risk reduction measures.

\begin{tabular}{|c|c|c|c|}
\hline Measure & $\begin{array}{l}\text { Structural measures } \\
\text { (scenario 1) }\end{array}$ & $\begin{array}{l}\text { Local action plan } \\
\text { (scenario } 2)\end{array}$ & $\begin{array}{l}\text { Local action plan and } \\
\text { structural measures (scenario 3) }\end{array}$ \\
\hline Discount rate $(\%)$ & 5 & 5 & 5 \\
\hline Life span (years) & 50 & 5 & 50 \\
\hline Implementation cost (EUR) & 43000000 & 10000 & 43000000 \\
\hline Maintenance cost $\left(\mathrm{EUR}_{\mathrm{yr}}{ }^{-1}\right)$ & 10000 & 2500 & 10000 \\
\hline Annualized cost $\left(\mathrm{EUR} \mathrm{yr}^{-1}\right)$ & 2253238 & 4700 & 2253238 \\
\hline Annualized cost & 2.25 & 0.00 & 2.25 \\
\hline $\begin{array}{l}\text { ACSLS (MEUR/life) } \\
\text { (compared with current situation) }\end{array}$ & -6.27 & -6.69 & $\mathrm{n} / \mathrm{a}$ \\
\hline $\begin{array}{l}\text { ACSLS (million EUR/life) } \\
\text { (compared with situation after im- } \\
\text { plementing local action plan) }\end{array}$ & $\mathrm{n} / \mathrm{a}$ & $\mathrm{n} / \mathrm{a}$ & -5.94 \\
\hline
\end{tabular}

Note: ACSLS is adjusted cost per statistical life saved; n/a is not applicable.

Table 8. Effect of the selection of flood protection level.

\begin{tabular}{|c|c|c|c|c|c|c|}
\hline \multirow[b]{2}{*}{$\begin{array}{l}\text { Flood } \\
\text { protection } \\
\text { level (years) }\end{array}$} & \multicolumn{2}{|c|}{ Oliva (scenario 0: CS) } & \multicolumn{2}{|c|}{ Valencia (region) } & \multicolumn{2}{|c|}{ Comparison local/ region } \\
\hline & $\begin{array}{l}\text { Societal risk } \\
\text { (AEAP) } \\
\text { (inhabitants } \mathrm{yr}^{-1} \text { ) }\end{array}$ & $\begin{array}{l}\text { Economic } \\
\text { risk }(\mathrm{AED}) \\
\left(\text { million EUR } \mathrm{yr}^{-1}\right)\end{array}$ & $\begin{array}{l}\text { Societal risk } \\
\text { (AEAP) } \\
\text { (inhabitants } \mathrm{yr}^{-1} \text { ) }\end{array}$ & $\begin{array}{l}\text { Economic } \\
\text { risk }(\mathrm{AED}) \\
(\text { million EUR yr} \\
-1\end{array}$ & $\%$ AEAP & $\%$ AED \\
\hline 1 & 2370 & 6.11 & No data & No data & - & - \\
\hline 2 & 2279 & 5.88 & 47600 & 746.24 & $4.8 \%$ & $0.8 \%$ \\
\hline 5 & 1991 & 5.16 & 29000 & 537.94 & $6.7 \%$ & $0.9 \%$ \\
\hline 10 & 1557 & 4.07 & 15800 & 348.04 & $9.8 \%$ & $1.2 \%$ \\
\hline
\end{tabular}

Note: CS is the current situation; AEAP is annual expected affected population; AED is annual expected damage costs.

\subsection{Effect of selected flood protection level}

In general, a flood protection level represents how well protected any given area is against flood damage. For example, a 10 -year flood protection system protects an area against anything equal to or smaller than a 10-year flood.

Risk analysis for the current situation has been performed by assuming that flood damage is zero for a 1-year flood event. In this section, the effect of such assumption is analysed.

As an example, results from Aqueduct Global Analyzer Database at regional scale are available for different protection levels. Model setup, results, and limitations of available estimations in this database can be found in Ward et al. (2013b) and Winsemius et al. (2013). Table 8 shows the results for the Valencian region from this database, accounting that there is a region-wide average protection level of 2-, 5-, and 10-year respectively.

Risk estimations for the current situation have been obtained for three different protection levels (i.e. assuming that flood damage is zero for 2-, 5-, and 10-year flood events) and are also summarized in Table 8.

Results show that societal risk in terms of AEAP would change from 2370 to 1557 inhabitants/year if a 10-year pro- tection level is assumed. Since there is no information on system response for flood events with low return periods (hydraulic modelling was conducted from 25 up to 500-year flood events), it is noted that risk estimated for the current situation might be overestimated for this case study. Further research on system response for high-frequency flood events would be of paramount interest.

We highlight that societal risk for the city of Oliva represents a significant percentage of total flood risk at regional scale when results are compared with those presented by Aqueduct Global Analyzer Database. Despite accounting for $1 \%$ of resident population at regional level, societal risk ranges from 5 to $10 \%$, depending on the protection level, as shown in Table 8.

Results from local flood risk analyses, as described in this paper, can be used to validate/update available information in global databases.

\subsection{Effect of including seasonal population variability on societal risk}

The impact of occupancy rates in hotels and campsites on societal risk has been assessed. Two situations are considered: 

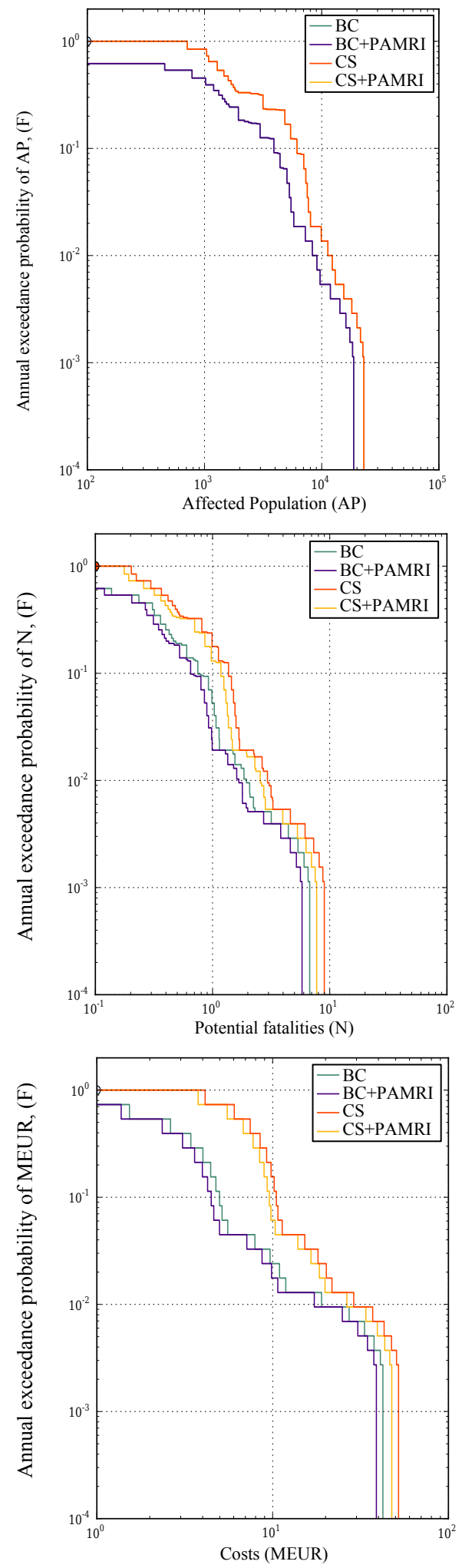

Figure 7. Extract of F-AP, F-N, and F-D curves for the case study: scenarios 0 (current situation), scenario 1 (PAMRI = local action plan), scenario 2 (structural measures), and scenario 3 (PAMRI and structural measures).
- occupation rates set to 0 , in which only census data and people in dispersed housing are used for estimating population at risk;

- occupation rates set to maximum plausible values (50\% in winter and $100 \%$ in summer).

Incorporating the above input data on consequence estimation into the risk model, societal risk results for these two scenarios show that values would range from 1940 affected population $\mathrm{yr}^{-1}$ and 0.38 lives $\mathrm{yr}^{-1}$ (low occupancy) to 2529 affected population $\mathrm{yr}^{-1}$ and 0.63 lives $\mathrm{yr}^{-1}$ (high occupancy). Results show that affected population increases in 450 inhabitants $\mathrm{yr}^{-1}$ when comparing zero occupancy's results to the current situation's results.

These results show the importance of not only analysing census data but also considering potential population in hotels and campsites. This population group is of high relevance in tourist cities, as it is the case on the Mediterranean coast of Spain.

\subsection{Effect of population trends on societal risk}

Flood risk in the future can be influenced either by climate change, which may increase or decrease the frequency and severity of flooding, or by socioeconomic changes, such as ageing population (or decline) and economic growth.

In this section, socioeconomic change is considered. The database of shared socioeconomic pathways developed by IIASA (International Institute for Applied Systems Analysis) is used for defining population trends in Oliva, based on national population trends for Spain in 2030 and 2050 (Nakicenovic et al., 2013). This database has been also used in recent local flood risk assessments (Ward et al., 2013a) in Europe.

For the current situation, resident and seasonal populations are increased by a factor of 1.06 and 1.13 in 2030 and 2050 respectively. Estimating societal risk for these two scenarios, risk would range from 2370 affected population $\mathrm{yr}^{-1}$ and 0.56 lives $\mathrm{yr}^{-1}$ (current situation) to 2616 affected population $\mathrm{yr}^{-1}$ and 0.61 lives $\mathrm{yr}^{-1}$ in 2050 .

Results show that attention should be paid on future population trends and urban developments to update vulnerability assessments.

\subsection{Effect of selection of depth-damage curves and asset values on economic risk}

The stage damage function used for this case study is the curve proposed in PATRICOVA (Generalitat Valenciana, 2015) for meso-scale flood risk analysis in the Valencian region, denoted as CS-curve. This curve has been compared to other relative (in percentage of damage) depth-damage functions. These curves are shown in Fig. 8 and include 
Table 9. Reference costs in EUR $\mathrm{m}^{-2}$ in urban areas: GVA (2015) and MAGRAMA (2013).

\begin{tabular}{lllllllll}
\hline Land use type & Warehouse & Commercial & Cultural & Industrial & Office & Households & Health services & Agricultural \\
\hline GVA & 11.25 & 34.55 & 34.55 & 11.25 & 34.55 & 68.7 & 34.55 & 0.8 \\
MAGRAMA & 150 & 380 & 200 & 450 & 380 & 350 & 200 & 5 \\
\hline
\end{tabular}

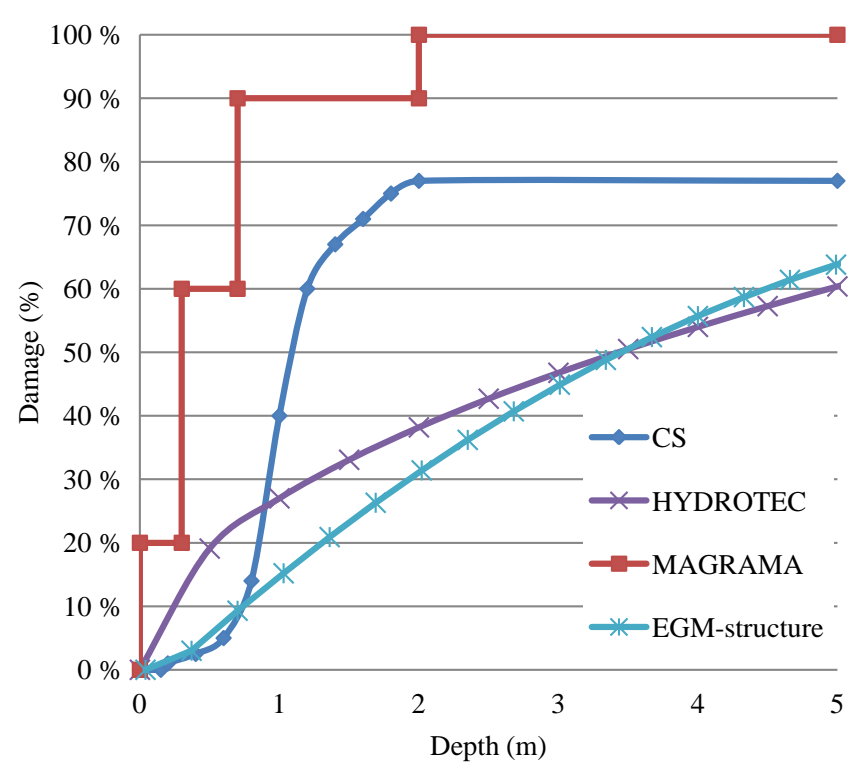

Figure 8. Examples of depth-damage functions compared to function used for the case study analysis (CS).

- MAGRAMA, the stage damage function proposed by MAGRAMA for flood risk analysis and mapping at river basin scale (MAGRAMA, 2013);

- EGM, the stage damage function proposed by USACE, based on empirical data from flood events from 1995 to 1997, developed for nation-wide applicability in flood damage reduction studies (USACE, 2000);

- HYDROTEC, a simple curve used for some flood action plans in Germany (Merz and Thieken, 2009).

These generalized functions represent some of the existent depth damage curves for assessing urban flood damage. From results shown in Fig. 8 and compared with other depthdamage functions in the literature, it is noted that CS and MAGRAMA curves may tend to overestimate costs. However, both curves include content damage in reference costs to be multiplied by damage percentages; thus no additional costs to content should be considered.

Depth-damage functions should ideally be developed for specific characteristics of local building types. Some examples of site-specific stage damage functions in Spain can be found (Velasco et al., 2015). However, the development of synthetic curves for each urban area requires an exhaustive field work, data gathering, and later analysis, which is not feasible in many cases.

Defining regionally specific stage damage functions for most relevant land use types would be desirable and useful for comparison among cities. In addition, detailed local data on building types (not available for this study) would be of interest to estimate direct flood damages in future analyses.

Reference values per land use type used for this case study correspond with rates proposed in PATRICOVA (Generalitat Valenciana, 2015). Direct costs for cleanup expenses, emergency prevention actions, and other related costs are not included. Table 9 shows reference values per land use type proposed by MAGRAMA for river basin flood risk analysis and mapping. These rates include replacement costs for infrastructure, content, and vehicles. Therefore, reference values differ from those proposed in PATRICOVA (Generalitat Valenciana, 2015).

By matching land use categories defined by both sources (Generalitat Valenciana, 2015; MAGRAMA, 2013), risk is estimated for the current situation by adopting new reference costs and the stage damage function shown in Fig. 8.

It is noted that economic risk outcomes are highly sensitive to the stage damage function and reference values adopted, since economic risk would increase from EUR 6.11 million $\mathrm{yr}^{-1}$ (for the current situation) to EUR 180.4 million $\mathrm{yr}^{-1}$ (for the current situation, but using proposed values by MAGRAMA). These results show the need for standardized stage damage functions and reference asset values in Spain.

\section{Discussion}

The proposed framework and its application to a real case study in Spain shows how risk analyses provide information to gain knowledge about the system, the potential flood events that can happen, and their consequences. Hence, risk analyses, as presented in this article, inform decision-makers but may not capture all aspects of risk and uncertainties that may be important for making effective decisions. Therefore, in this section, limitations of the proposed framework and implications of flood risk analysis outcomes to local action planning are described, along with recommendations for improved flood risk analysis. 


\subsection{Limitations}

The analysis framework used in this study is relatively straightforward, but it does allow one to analyse risk and to assess the impact of different scenarios. It is proposed as a framework for enhancing local flood risk analysis at regional and national scale, potentially transferable to other local applications in Europe.

However, the following remarks are made.

- Type of flooding: in this paper, we analysed river flooding but integrating multiple hazards would be of great interest in future upgrades (e.g. to analyse the influence of sea water levels in boundary conditions).

- Flood hazard: it is recognized that overestimations of annual risk between 33 and $100 \%$ have been reported in other studies when only three return periods are used (Ward et al., 2011). Therefore, results suggest that results for the case study could benefit from paying more attention to the potential damage caused by highprobability flood events. As shown in Sect. 4.1, highprobability flood event analysis would help to better adjust existing protection levels and would be of interest for future upgrades (e.g. return periods of 5 and 10 years).

- Economic consequence estimation: a generic relative stage damage function is used for the case study, based on methods used for regional planning. In addition, due to the lack of statistical information on building-specific asset values, available rates by land use type have been used in this analysis, although more suitable for macroscale flood damage evaluations. As shown in Sect.4.4, information on building typology at micro-scale would be of interest for future upgrades.

- Life-loss estimation: sources of uncertainty include lack of data on detailed building typology (to better estimate area vulnerability), human behaviour, and effectiveness of warning systems, among other factors. Sensitivity analyses indicate that societal risk for this case study is dominated by population concentrated in highly vulnerable areas and seasonal variability. As shown in Sect. 4.2, societal risk may range from 1940 affected population $\mathrm{yr}^{-1}$ (low occupancy) to 2529 affected population $\mathrm{yr}^{-1}$ (high occupancy), thus requiring good knowledge of population variations during the year.

- Vulnerability: other factors influence flood damage, such as flow velocity, contamination, building materials and quality, etc., but are not considered in this analysis, since there is no available information on detailed building typology nor site-specific vulnerability functions to incorporate the impact of flow velocity or debris flow. In future upgrades, it would be of interest to analyse vulnerability including such factors, as analysed for other cases in Europe (Quan-Luna et al., 2011; Totschnig and Fuchs, 2013).

\subsection{Recommendations for flood risk analysis}

Based on results from this analysis, we recommend that quantitative risk analyses become the basis for developing local flood risk management plans. Specific recommendations include the following.

- Upgrading hydraulic modelling to a broad set of flood events for hazard mapping and analysing not only river flooding but also pluvial or coastal flooding. As shown in Sect. 4.1, flood hazard mapping should be performed for high-probability flood events.

- Improved data gathering on population characteristics and distribution at local scale. As shown in Sect. 4.2, detailed information on population distribution and variability is required to better analyse risk, including daily and seasonal variations.

- Improved land use data gathering at local scale for better analyse life-loss and economic consequences from flooding. As shown in Sect. 4.4, obtaining detailed data on building and asset characteristics would enable economic consequence analysis at micro-scale then improving the definition of asset values and better estimating economic risks.

- Defining standardized relative stage damage functions and reference costs at national scale. As shown in Sect. 4.4, both local and river basin flood risk analysis should consider the same method for economic consequence estimation to allow comparative analysis, to upgrade current and future flood risk plans, and to develop cost-benefit analysis for prioritizing flood risk reduction measures.

- Characterizing risk awareness and better analysing effectiveness of evacuation procedures in case of emergency by incorporating outcomes from social research (as, for example, described in Escuder-Bueno et al., 2012) towards a multi-disciplinary paradigm (including technical, policy, and social aspects).

Authors acknowledge the fact that micro-scale quantitative flood risk analysis may require advanced know-how and expertise on risk analysis. However, the development and application of methods such the presented work in this paper will help local authorities to guide future analysis. In most cases, resources have already been allocated for conducting flood hazard analysis, thus requiring only updating or further upgrading based on aforementioned recommendations and their combination with consequence estimation analysis. 


\subsection{Local action planning implications}

Results from the case study demonstrate its applicability and usefulness to support decision making for local action planning. As described in Sect. 3.10, implementation costs are lower than benefits in terms of economic risk reduction (ACSLS values are negative).

The application of the proposed framework for quantifying local flood risk for the city of Oliva represents a novel analysis in Spain.

The following recommendations were made to local authorities for defining strategies for local action planning, derived from outcomes of conducted flood risk analysis.

- Definition of specific public education campaigns for resident and seasonal population, with emphasis in high vulnerable groups (e.g. the elderly, schools, and campsites), as described in Sect. 3.6, lower vulnerable rates are assumed for scenarios 2 and 3. This assumption should be supported by better public education and warning schemes.

- Definition of a procedure to formally reporting flood events, damages, and effect of communication and evacuations procedure is required for future updates of hazard and vulnerability analysis. This would enable to validate assumptions concerning the impact on flood consequences (lower area vulnerability and damages) of implementing the local action plan.

- Verification of established communication schemes between regional and local authorities and with emergency and civil protection services is needed to ensure effectiveness of non-structural measures for flood risk reduction (reduced damages bases on available warning times).

- Identification of potential locations for assembly points and helicopter landing sites have been set based on population clusters, hazard maps, and available evacuation routes; developed risk maps (examples are included in Supplement) were used to identify potential locations. These sites should be verified and reviewed in future updates.

- Data gathering on additional urban characteristics (e.g. building typology, daily variability of population in industrial and commercial areas) would upgrade risk analyses and provide improved outcomes for decision making. As shown in Sect. 4.2., societal risk is highly influenced by seasonal variability.

- Impact of future flood risk mitigation measures: as shown in Sect. 3.10, new risk reduction measures might be planned and evaluated in accordance with the ACSLS indicator (e.g. aiming at reducing annual expected affected population). The proposed framework for flood risk analysis will allow updating in future reviews of the local action plan.

Up to now, risk reduction actions were focused on reducing flood hazard and exposure. All the aforementioned recommendations are provided to enhance flood risk management from a broader perspective towards smart flood risk governance (including hazard, exposure, and vulnerability analysis, as part of a risk-informed and collaborative decisionmaking process for local flood risk management).

\section{Conclusions and the way forward}

Quantification of societal and economic flood risk is not required by current legislation in Spain and is relatively novel in local flood risk management as a result of a lack of guidance, standardized methods, or tools for local flood risk analysis. Examples can be found in other countries such as in England and Wales (Hall et al., 2003) but are still scarcely applied in Spain.

The main scope of this study was to propose a common framework for quantitative flood risk analysis at local scale and to analyse urban flood risk for the city of Oliva.

Local authorities are currently developing the local action plan against flooding for Oliva, as required by regional legislation. Results from the flood risk analysis described in this paper have informed local authorities to define strategies and to make decisions on upcoming public education campaigns and training activities. In addition, assembly and monitoring points have been identified based on conducted flood risk analyses and identified hazard levels.

Results show that societal and economic risks, while considerably reduced from planned structural measures (a dam is now under construction), are still significant, but they can be further reduced through local action planning.

The results of this study show that improved communications schemes and verified warning systems could significantly decrease flood risk. These results can be used to support risk communication and increase risk awareness.

Sensitivity of existent flood risk to vulnerability estimations has been addressed and future scenarios have been compared with the current situation.

Existent hazard maps have been used for identifying affected areas. A broad range of hydraulic simulations, covering five to seven return periods, would be desirable (Ward et al., 2011). In addition, further research to analyse dam failure scenarios and the impact of climate change on system response is recommended.

A more comprehensive risk analysis can be carried out to include other sources of flood hazards such as pluvial or coastal flooding. The combination of multiple flood hazards should be taken into account in future risk analyses. Cities affected by multiple hazards may benefit from the application of structured frameworks for flood risk analysis as the approach presented in this paper (and available examples 
for other hazard types), towards a comprehensive and multihazard flood risk analysis.

Further research on the impact on risk of mitigation measures (including data gathering through workshops or surveys) could inform local actors on the definition of incentives for flood risk mitigation.

The presented approach can be potentially applied by other cities to perform similar flood risk analysis. There is still a long way to go in the development and implementation of local action plans against flooding. The study described in this paper aims to become a reference example for other cities towards improved flood risk management.

\section{Code and data availability}

iPresas UrbanSimp is available for download at www. ipresas.com.

Flood hazard maps and the local action plan are available to the public at www.oliva.es (in Spanish). GIS-based local data are not publicly accessible due to its protection level (owned by local authorities).

\section{Team list}

Jesica T. Castillo-Rodríguez: civil engineer (EQF7, 2008) and MEng in hydraulic engineering and environment (EQF7, 2012); researcher and $\mathrm{PhD}$ student at the (Polytechnic University of Valencia, UPV), with more than 5 years of research experience in flood risk analysis and risk-informed dam safety management, through several national and EUfunded research projects and private contracts, as well as developing local action plans against flood risk. She is currently developing her $\mathrm{PhD}$ on the application of risk analysis techniques toward an integrated flood risk management by incorporating multiple hazards (natural and manmade risks).

Ignacio Escuder-Bueno: MSCE in civil engineering (1996) and PhD (2001); professor at the Universitat Politècnica de València (UPV), and promoter and founder associate of iPresas (a technology based spin-off company of the UPV); secretary-general of the International Commission on Large Dams (ICOLD) European Club since 2010 and full elected member of the Spanish National Committee on Large Dams (SPANCOLD) since 2007; visiting professor at the University of Maryland (2014) and Utah State University (2006) and teaching assistant at the University of Wisconsin (1995-1996); coordinator of national and EU-funded research projects on risk analysis, critical infrastructure management, and energy efficiency (e.g. E ${ }^{2}$ STORMED).

Sara Perales-Momparler: civil engineer (EQF7, 2002) and $\mathrm{PhD}$ (2015) from the Polytechnic University of Valencia (UPV); independent consultant (Green Blue Management) and director of PMEnginyeria, consultancy firm specialized in sustainable drainage systems (SuDS), from 2006 to 2013.
She worked for Sinclair Knight Merz (SKM), an international consultancy firm, both in the United Kingdom and New Zealand from 2004 to 2006 and has participated in several EU-funded research projects on flood risk analysis, SuDS, water, and energy efficiency (e.g. AQUAVAL, $\mathrm{E}^{2}$ STORMED).

Juan Ramón Porta Sancho: bachelor's degree in technical architecture (EQF6, 1983 and 2011) and master's degree in urban emergency prevention and management (1992) from the Polytechnic University of Valencia (UPV); technical architect at the Oliva City Council since 1992; head of Urban Management and Civil Protection Division; he has coordinated and supervised urban planning studies and works for nearly 30 years (co-author of the Territorial Emergency Plan of Oliva, 1994), and, more recently, projects for implementing GIS-based systems at local scale and flood risk studies in Oliva; he is currently coordinating the development of the Municipal Action Plan against Flood Risk for the city of Oliva, as technical director. He has also participated in several EU-funded research projects (e.g. QUATER, DAMAGE).

\section{The Supplement related to this article is available online at doi:10.5194/nhess-16-1699-2016-supplement.}

Author contributions. Jesica Tamara Castillo-Rodríguez and Ignacio Escuder-Bueno proposed the method and tools for flood risk analysis. Jesica Tamara Castillo-Rodríguez performed analyses and prepared the manuscript, in close collaboration with all co-authors (discussion of methods and tools, results and conclusions). Sara Perales-Momparler has developed the Local Action Plan (PAMRI) for the city of Oliva including outcomes from this study, following a risk-informed approach, with contributions of all co-authors in a joint science-policy effort. Juan Ramón PortaSancho has contributed to the acquisition, analysis of data, and interpretation of results and supervised all activities concerning the development and approval of the Local Action Plan (PAMRI).

Acknowledgements. This research was conducted within the framework of the INICIA project, funded by the Spanish Ministry of Economy and Competitiveness (BIA2013-48157-C2-1-R). The article processing charges for this open-access publication will be covered by the INICIA project. We would like to thank the city of Oliva for their willingness to share data, knowledge, and experience with the authors and for initiating this risk-informed journey.

Edited by: S. Fuchs

Reviewed by: two anonymous referees 


\section{References}

Barredo, J. I.: Normalised flood losses in Europe: 1970-2006, Nat. Hazards Earth Syst. Sci., 9, 97-104, doi:10.5194/nhess-9-972009, 2009.

Castillo-Rodriguez, J. T., Escuder-Bueno, I., Altarejos-García, L., and Serrano-Lombillo, A.: The value of integrating information from multiple hazards for flood risk analysis and management, Nat. Hazards Earth Syst. Sci., 14, 379-400, doi:10.5194/nhess14-379-2014, 2014.

DEFRA: FD2321/TR1 - The Flood Risks to People Methodology, London, available at: www.defra.gov.uk/environ/fcd/research (last access: February 2016), 2006.

EC: Guide to Cost Benefit Analysis of Investment Projects: European Commission, DG for Regional and Urban Policy, Brussels BELGIUM, doi:10.2776/97516, 2008.

Escuder-Bueno, I., Castillo-Rodriguez, J. T., Zechner, S., Jöbstl, C., Perales-Momparler, S., and Petaccia, G.: A quantitative flood risk analysis methodology for urban areas with integration of social research data, Nat. Hazards Earth Syst. Sci., 12, 2843-2863, doi:10.5194/nhess-12-2843-2012, 2012.

European Parliament: DIRECTIVE 2007/60/EC OF THE EUROPEAN PARLIAMENT AND OF THE COUNCIL of 23 October 2007 on the assessment and management of flood risks, L 228, 27-34, 2007.

Fell, R., Corominas, J., Bonnard, C., Cascini, L., Leroi, E., and Savage, W. Z.: Guidelines for landslide susceptibility, hazard and risk zoning for land use planning, Eng. Geol., 102, 85-98, doi:10.1016/j.enggeo.2008.03.022, 2008.

Fuchs, S., Spachinger, K., Dorner, W., Rochman, J., and Serrhini, K.: Evaluating cartographic design in flood risk mapping, Environ. Hazards, 8, 52-70, doi:10.3763/ehaz.2009.0007, 2009.

Fuchs, S., Keiler, M., and Zischg, A.: A spatiotemporal multihazard exposure assessment based on property data, Nat. Hazards Earth Syst. Sci., 15, 2127-2142, doi:10.5194/nhess-152127-2015, 2015.

Gamper, C. D. and Turcanu, C.: On the governmental use of multi-criteria analysis, Ecol. Econ., 2, 298-307, doi:10.1016/j.ecolecon.2007.01.010, 2007.

Generalitat Valenciana: Plan de Acción Territorial sobre prevención del Riesgo de Inundación en la Comunitat Valenciana (PATRICOVA), Valencia, 67-72, 2015.

Hall, J. W., Meadowcroft, I. C., Sayers, P. B., and Bramley, M. E.: Integrated Flood Risk Management in England and Wales, 2003.

Hennig, C., Dise, K., and Muller, B.: Achieiving Public Protection with Dam Safety Risk Assessment Practices, Nat. Hazards Rev., 4, 126-135, doi:10.1061/(ASCE)15276988(2003)4:3(126)1997, 2003.

Hijós Bitrián, F., Mañueco Pfeiffer, M. G., and Segura Notario, N.: Comité nacional español de grandes presas, Congreso Nacional de Presas, Proc. of Risk-Based Decision Making in Water Resources VIII, edited by: Yacov, Y., Haimes, D., Moser, A., and Stakhiv, E. Z., 19-32, 2010.

Jongman, B., Kreibich, H., Apel, H., Barredo, J. I., Bates, P. D., Feyen, L., Gericke, A., and Neal, J.: Comparative flood damage model assessment?: towards a European approach, Nat. Hazards Earth Syst. Sci., 12, 3733-3752, doi:10.5194/nhess-12-37332012, 2012.

Jongman, B., Koks, E. E., Husby, T. G., and Ward, P. J.: Increasing flood exposure in the Netherlands: implications for risk financing, Nat. Hazards Earth Syst. Sci., 14, 1245-1255, doi:10.5194/nhess-14-1245-2014, 2014.

Jonkman, S. N., Vrijling, J. K., and Vrouwenvelder, A. C. W. M.: Methods for the estimation of loss of life due to floods?: a literature review and a proposal for a new method, Nat. Hazards, 46, 353-389, doi:10.1007/s11069-008-9227-5, 2008.

Klijn, F. and Schweckendiek, T.: Comprehensive Flood Risk Management: Research for Policy and Practice, CRC Press, Boca Raton, 297-330, 2012.

Klijn, F., Kreibich, H., De Moel, H., and Penning-rowsell, E.: Adaptive flood risk management planning based on a comprehensive flood risk conceptualisation, Mitig. Adapt. Strat. Glob. Chang., 20, 845-864, doi:10.1007/s11027-015-9638-z, 2015.

MAGRAMA: Propuesta de mínimos para la metodología de realización de los mapas de riesgo de inundación, Madrid, Ministerio de Agricultura, Alimentación y Medio Ambiente, Madrid, Spain, 2013.

Marcotullio, P. J. and McGranahan, G.: Scaling Urban Environmental Challenges: From local to global and back, Earthscan with UNU-IAS and IIED, Earthscan, London, Sterling, VA, 2006.

Mayors Adapt: The new integrated covenant of mayors for climate and energy, www.mayors-adapt.eu (last access: July 2016), 2015.

Mazzorana, B., Comiti, F., Scherer, C., and Fuchs, S.: Developing consistent scenarios to assess fl ood hazards in mountain streams, J. Environ. Manage., 94, 112-124, doi:10.1016/j.jenvman.2011.06.030, 2012.

Mazzorana, B., Comiti, F., and Fuchs, S.: A structured approach to enhance flood hazard assessment in mountain streams, Nat. Hazards, 67, 991-1009, doi:10.1007/s11069-011-9811-y, 2013.

Merz, B. and Thieken, A. H.: Flood risk curves and uncertainty bounds, Natural Hazards, 51, 437-458, doi:10.1007/s11069-0099452-6, 2009.

Merz, B., Kreibich, H., Schwarze, R., and Thieken, A.: Assessment of economic flood damage, Nat. Hazards Earth Syst. Sci., 16971724, doi:10.5194/nhess-10-1697-2010, 2010.

Meyer, V., Scheuer, S., and Haase, D.: A multicriteria approach for flood risk mapping exemplified at the Mulde river, Germany, Nat. Hazards, 48, 17-39, doi:10.1007/s11069-008-9244-4, 2009.

Meyer, V., Kuhlicke, C., Luther, J., Fuchs, S., Priest, S., Dorner, W., Serrhini, K., Pardoe, J., and Mccarthy, S.: Recommendations for the user-specific enhancement of flood maps, Nat. Hazards Earth Syst. Sci., 12, 1701-1716, doi:10.5194/nhess-12-17012012, 2012.

Miller, A., Jonkman, S. N., and Van Ledden, M.: Risk to life due to flooding in post-Katrina New Orleans, Nat. Hazards Earth Syst. Sci., 15, 59-73, doi:10.5194/nhess-15-59-2015, 2015.

Morales-Torres, A., Serrano-Lombillo, A., Escuder-Bueno, I., and Altarejos-García, L.: The suitability of risk reduction indicators to inform dam safety management, Struct. Infrastruct. Eng., 12, 2479, doi:10.1080/15732479.2015.1136830, 2016.

Nakicenovic, N., Lempert, R., and Janetos, A.: Special Issue of Climatic Change on the framework for the development of new socioeconomics scenarios for climate change research, Clim. Change, 122, 351-361, doi:10.1007/s10584-013-0982-2, 2013.

Parker, D. J., Tunstall, S., and Wilson, T.: Socio-Economic Benefits of Flood Forecasting and Warning, in: International conference on innovation advances and implementation of flood forecasting technology, Session 8, 1-11, ACTIF, available at: http:// 
www.actif-ec.net/conference2005/proceedings/index.html, (last access: July 2016), Tromso, Norway, 2005.

Penning-Rowsell, E. C., Priest, S. J., Parker, D. J., Morris, J., Tunstall, S. M., Viavatenne, C., Chatterton, J., and D., O.: Flood and Coastal Erosion Risk Management, A manual for economic appraisal, London, Routledge, Chapter 4, 2013.

Quan-Luna, B., Blahut, J., Westen, C. J. Van, Sterlacchini, S., Asch, T. W. J., and Van and Akbas, S. O.: The application of numerical debris flow modelling for the generation of physical vulnerability curves, Nat. Hazards Earth Syst. Sci., 11, 2047-2060, doi:10.5194/nhess-11-2047-2011, 2011.

Ramis, C., Homar, V., Amengual, A., Romero, R., and Alonso, S.: Daily precipitation records over mainland Spain and the Balearic Islands, Nat. Hazards Earth Syst. Sci., 13, 2483-2491, doi:10.5194/nhess-13-2483-2013, 2013.

Sayers, P. B., Horritt, M., Penning-Rowsell, E., and McKenzie, A.: Climate Change Risk Assessment 2017 Projections of future flood risk in the UK, London, 69-73, 2015.

Serrano-Lombillo, A., Escuder-Bueno, I., De Membrillera-Ortuño, M. G., and Altarejos-García, L.: Methodology for the Calculation of Annualized Incremental Risks in Systems of Dams, Risk Anal., 31, 1000-1015, doi:10.1111/j.1539-6924.2010.01547.x, 2011.

Totschnig, R. and Fuchs, S.: Mountain torrents: Quantifying vulnerability and assessing uncertainties, Eng. Geol., 155, 31-44, doi:10.1016/j.enggeo.2012.12.019, 2013.

UK Health and Safety Executive: Reducing Risks: Protecting People - HSE's decision making process, Norwich, Health and Safety Executive, 40-48, 2001.
Université Catholique de Louvain: EM-DAT Database: The OFDA/CRED International Disaster Database, available at: http: //www.emdat.be/ (last access: 1 October 2015), 2015.

USACE: Economic Guidance Memorandum (EGM) 01-03: Generic Depth-Damage Relationships, 2000.

Velasco, M., Cabello, À., and Russo, B.: Flood damage assessment in urban areas, Application to the Raval district of Barcelona using synthetic depth damage curves, Urban Water J., doi:10.1080/1573062X.2014.994005, 2015.

Vrijling, J. K.: Probabilistic design of water defense systems in The Netherlands, 74, 337-344, 2001.

Ward, P. J., De Moel, H., and Aerts, J. C. J. H.: How are flood risk estimates affected by the choice of return-periods?, Nat. Hazards Earth Syst. Sci., 11, 3181-3195, doi:10.5194/nhess-113181-2011, 2011.

Ward, P. J., Jongman, B., Weiland, F. S., Bouwman, A., Beek, R. Van, Bierkens, M. F. P., and Ligtvoet, W.: Assessing flood risk at the global scale: model setup, results, and sensitivity, Environ. Res. Lett., 044019, doi:10.1088/1748-9326/8/4/044019, 2013 a.

Ward, P. J., Jongman, B., Weiland, F. S., Bouwman, A., van Beek, R., Bierkens, M. F. P., Ligtvoet, W., and Winsemius, H. C.: Assessing flood risk at the global scale: model setup, results, and sensitivity, Environ. Res. Lett., 8, 044019, doi:10.1088/17489326/8/4/044019, 2013b.

Winsemius, H. C., Van Beek, L. P. H., Jongman, B., Ward, P. J., and Bouwman, A.: A framework for global river flood risk assessments, Hydrol. Earth Syst. Sci., 17, 1871-1892, doi:10.5194/hess-17-1871-2013, 2013. 